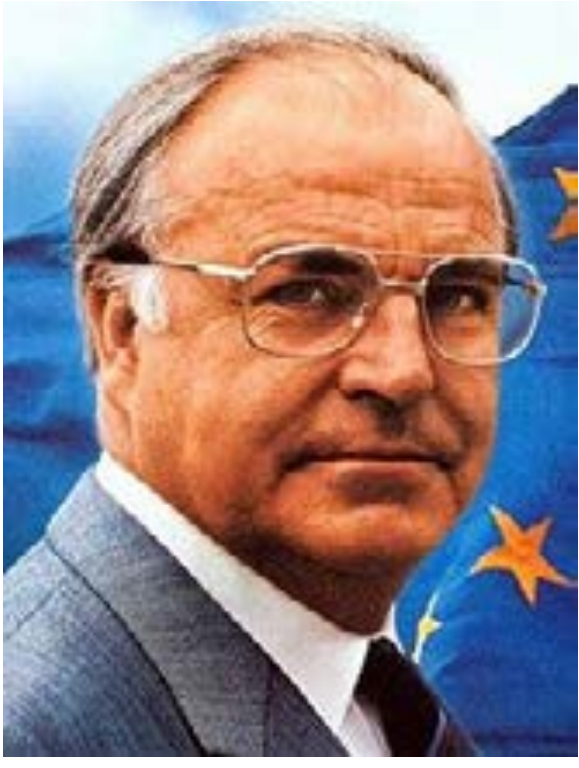

Helmut Josef Michael Kohl; 3 April 1930 - 16 June 2017) was a German statesman who served as Chancellor of Germany from 1982 to 1998 (of West Germany 1982-1990 and of the reunited Germany 1990-1998) and as the chairman of the Christian Democratic Union (CDU) from 1973 to 1998. From 1969 to 1976, Kohl was minister president of the state Rhineland-Palatinate. Kohl chaired the Group of Seven in 1985 and 1992.

Born in 1930 in Ludwigshafen to a Roman Catholic family, Kohl joined the Christian Democratic Union in 1946 at the age of 16 . He earned a PhD in history at Heidelberg University in 1958 and worked as a business executive before becoming a full-time politician. He was elected as the youngest member of the Parliament of RhinelandPalatinate in 1959 and became Minister-President of his home state in 1969. Viewed during the 1960s and the early 1970s as a progressive within the CDU, he was elected national chairman of the party in 1973. In the 1976 federal election his party performed well, but the government of social democrat Helmut Schmidt was able to remain in power. In 1982 Kohl was elected Chancellor after the liberal Free Democratic Party had switched sides to support the CDU. After he became party leader, Kohl was increasingly seen as a more conservative figure.

As Chancellor Kohl was strongly committed to European integration and French-German cooperation in particular; he was also a steadfast ally of the United States and supported Reagan's more aggressive policies in order to weaken the Soviet
Union. Kohl's 16-year tenure was the longest of any German Chancellor since Otto von Bismarck. He oversaw the end of the Cold War and is widely regarded as the mastermind of German reunification. Together with French President François Mitterrand, Kohl was the architect of the Maastricht Treaty, which established the European Union (EU) and the euro currency. ${ }^{[1]}$ Kohl was also a central figure in the eastern enlargement of the European Union, and his government led the effort to push for international recognition of Croatia, Slovenia and Bosnia and Herzegovina when the states declared independence. He played an instrumental role in solving the Bosnian War. Domestically, Kohl's policies focused on economic reforms and later also on the process of integrating the former East Germany into the reunited Germany, and he moved the federal capital from the "provisional capital" Bonn back to Berlin. Kohl also greatly increased federal spending on arts and culture. After his chancellorship, Kohl's reputation suffered domestically because of his role in the CDU donations scandal, but it was largely rehabilitated in later years. The later Chancellor Angela Merkel started her political career as Kohl's protegée. Kohl died on 16 June 2017, age 87; he was honored with a state funeral following his death. Kohl was described as "the greatest European leader of the second half of the 20th century" by U.S. Presidents George H. W. Bush ${ }^{[2]}$ and Bill Clinton. ${ }^{[3]}$ Kohl received the Charlemagne Prize in 1988 with François Mitterrand; in 1998 Kohl became the second person to be named Honorary Citizen of Europe by the European heads of state or government. Following his death, Kohl was honored with the first ever European Act of State in Strasbourg. ${ }^{[4]}$ Kohl was married to Hannelore Kohl during his entire political career, and they had two sons, Walter Kohl and Peter Kohl.

Source: Wikipedia

\section{World University Rankings}

World Reputation Rankings 2017: launch event announced

\section{World University Rankings}

https://www.timeshighereducation.com/worlduniversity-rankings 
BRICS \& Emerging Economies University Rankings 2017

https://www.timeshighereducation.com/worlduniversity-rankings/2017/brics-and-emergingeconomies-universityrankings\#!/page/0/length/25/sort_by/rank/sort_or der/asc/cols/stats

World Reputation Rankings 2017: launch event announced

https://www.timeshighereducation.com/worlduniversity-rankings/world-reputation-rankings2017-launch-event-announced

The Times Higher Education World Reputation Rankings 2017 will be launched at an event in Cambridge, Massachusetts, on 14 June.

The annual table of the world's top 100 most prestigious institutions will be published at $5 \mathrm{pm}$ (BST) in London (12pm Massachusetts time).

The ranking will be formally revealed at THE's first World Reputation Forum at The Charles Hotel, Harvard Square, Cambridge.
The invitation-only event will bring together experts in higher education branding and strategic communications with sector leaders to share approaches to building and managing reputation. It will also explore how universities can overcome the challenge of engaging successfully with the public in a post-truth environment.

The World Reputation Rankings are based on the results of THE's annual invitation-only Academic Reputation Survey, which was carried out between January and March 2017. It received responses from more than 10,500 scholars across 137 countries.

The survey asked published academics to outline which universities they perceived to be the best for teaching and research in their specialist discipline. Each respondent was asked to identify institutions worldwide and in their own country and represented many of their peers from their fields and their nation.

The 2017 survey results will also make up two of the 13 performance indicators used to create the THE World University Rankings 2017-18 and related regional rankings. 